Юрчик Г. М., к.е.н., доцент,

Дужар А. І., здобувач вищої освіти першого (бакалаврського) рівня (Національний університет водного господарства та природокористування, м. Рівне)

\title{
ЗАРОБІТНА ПЛАТА НА НАЦІОНАЛЬНОМУ РИНКУ ПРАЦІ: ДИНАМІЧНИЙ, РЕГІОНАЛЬНО-ГАЛУЗЕВИЙ ТА СОЦІАЛЬНИЙ АСПЕКТ
}

Досліджено основні тенденції в оплаті праці на національному ринку праці. Проаналізовано зміну номінальної та реальної заробітної плати, галузеву та регіональну диференціацію в оплаті праці. Обгрунтовано соціальну вразливість молоді та жінок на ринку праці щодо рівня їх заробітної плати. Виявлено особливості оплати праці за організаційними формами ведення бізнесу та у порівнянні 3 європейським ринком праці. Запропоновано пріоритетні напрями удосконалення регулювання оплати праці на національному ринку праці.

Ключові слова: заробітна плата; оплата праці; ринок праці; реальна заробітна плата; номінальна заробітна плата.

Вступ. Потреба формування в Україні соціально-орієнтованої ринкової економіки вимагає суттєвого підвищення добробуту населення. Головною економічною умовою підвищення рівня життя $\epsilon$ забезпечення переходу до високої вартості робочої сили і відповідно - до гідної заробітної плати. В Україні в сфері оплати праці накопичились значні проблеми: тривалий час утримується низький рівень заробітної плати; існує ї̈ надмірна міжгалузева диференціація; оплата праці в недостатній мірі пов'язана 3 продуктивністю праці та ефективністю виробництва. Ці та інші проблеми в сфері оплати праці вказують на те, що в Україні не сформовано ефективної системи її організації та регулювання.

Аналіз останніх досліджень. Проблему заробітної плати (ЗП) досліджували та продовжують досліджувати багато науковців, які сходяться в тому, що ЗП належить до базових категорій економічної науки. Серед вітчизняних вчених, у працях яких досліджено сутність заробітної плати та проблемні питання ефективної оплати праці, варто зазначити: В.Баранова, О.Грішнову, Н. Ільєнко, А. Калину,
А. Козаченко,
А. Колота,
О. Криворотько,
О. Крушельницьку, М. Семикіну. Серед зарубіжних публікацій щодо дослідження оплати праці відзначаються класичні роботи Ф. Герцберга, А. Маршалла, А. Маслоу, Д. Рікардо, П. Самуельсона, Ф. Тейлора та багато інших. 
Проте, проблема оплати праці потребує подальших досліджень, а саме, що стосується іï динамічного, регіонально-галузевого та соціального аспекту. Адже, побудова ефективного механізму регулювання ЗП потребує врахування особливостей та наявних проблем в сфері оплати праці.

Постановка завдання. Відтак, метою даної статті $\epsilon$ аналітичне дослідження тенденцій, особливостей та проблем у сфері оплати праці на національному ринку праці як передумови для іï ефективного регулювання.

Наукові результати. Дослідження показників оплати праці в Україні здійснюватиметься на основі офіційних статистичних даних за даними Державної служби статистики. Як свідчить аналіз (рис. 1) протягом 2014-2018 рр. середньомісячна заробітна плата в Україні невпинно зростала та у 2018 р. склала близько 8,9 тис. грн. При цьому темпи зростання номінальної ЗП протягом 2014-2018 рр. були досить значними та варіювали в межах від 6,0 до 37,1\%. Однак, в дійсності аналіз середньої ЗП в номінальному вираженні в умовах інфляції не є об'єктивним. Дослідження темпів зростання реальної ЗП в Україні свідчить, що у 2014-2015 рр. в Україні мало місце суттєве зниження реальної ЗП відповідно на 6,5\% та 20,2\%.

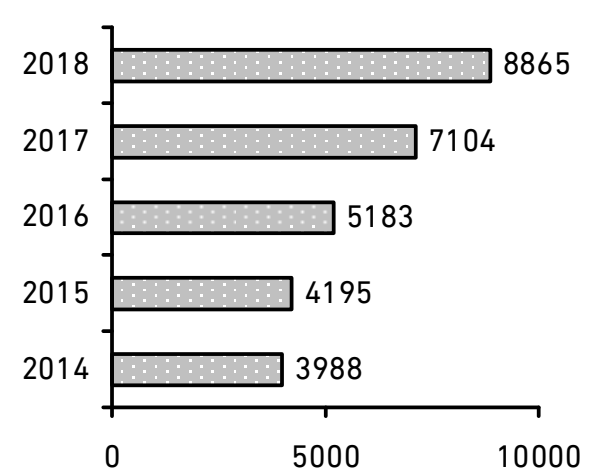

a)

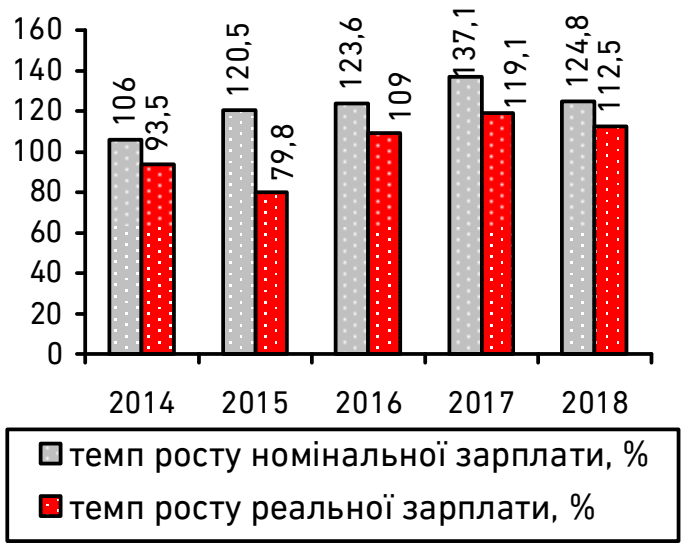

б)

Рис. 1. Динаміка середньомісячної заробітної плати в Україні:

а) грн/місяць; б) темп зростання, \% до попереднього року Джерело: побудовано автором на основі [4; 5]

В Україні спостерігається значна диференціація рівня оплати праці за видами економічної діяльності (ВЕД). Як свідчать розрахунки в усіх ВЕД середній розмір номінальної ЗП невпинно зростає. Проте, спостерігається значна диференціація рівня оплати праці за ВЕД (рис. 2). Найвищий рівень оплати праці в Україні спостерігається у фінансовій та страховій діяльності, інформаційній 
та телекомунікаційній галузі, професійній, науковій та технічній діяльності. В той же час, найнижчий рівень оплати праці спостерігається в охороні здоров'я та наданні соціальної допомоги, тимчасовому розміщуванні та організації харчування, сільському господарстві.

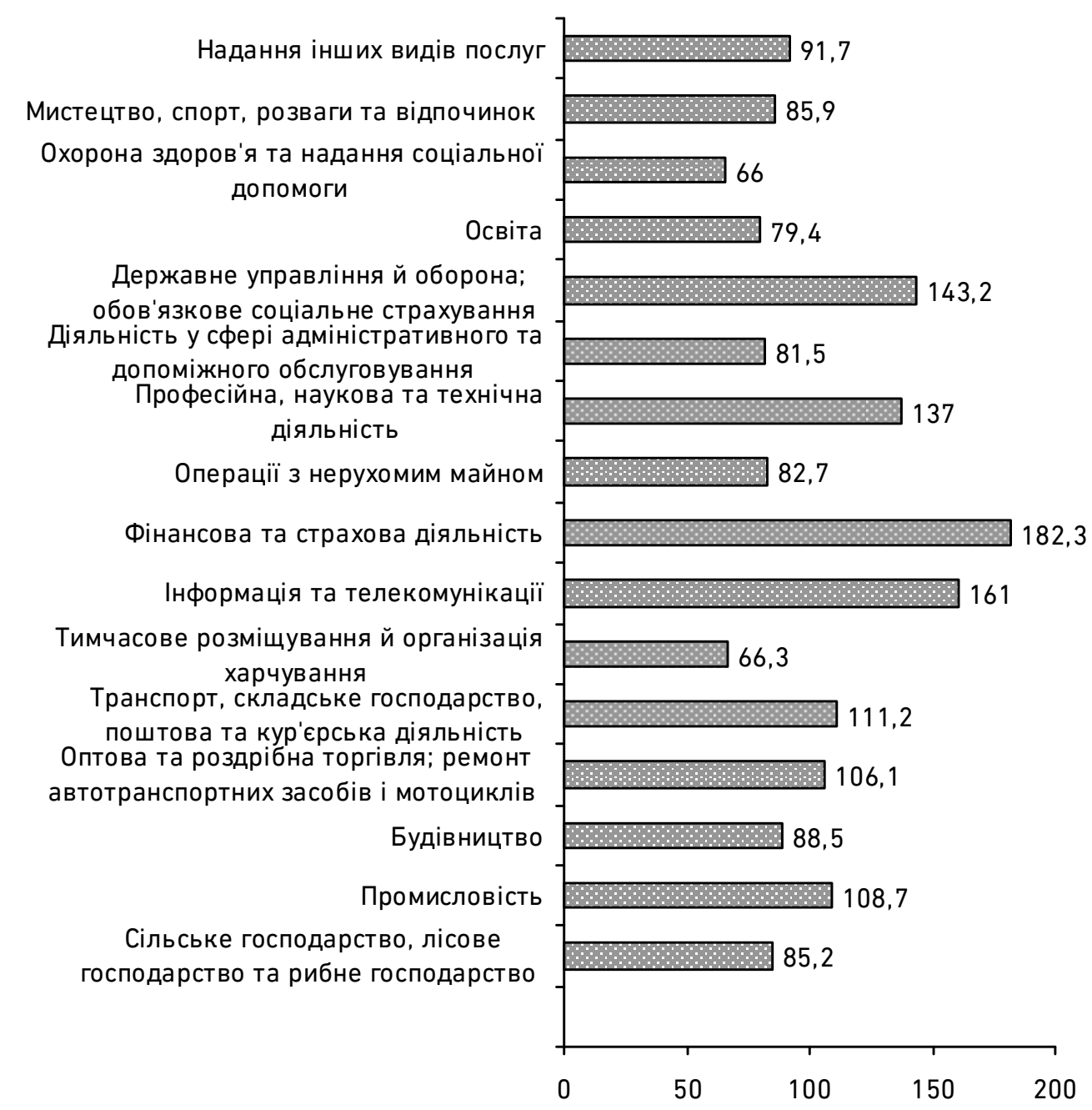

Рис. 2. Диференціація рівня оплати праці за ВЕД в Україні (2018р.), \% до середньої заробітної плати в національній економіці Джерело: побудовано автором на основі [4; 5]

Дослідження рівня оплати праці в регіональному розрізі свідчить про значну регіональну диференціацію ЗП в Україні (рис. 3). Так, найвищий рівень оплати праці традиційно спостерігається в м. Києві та Київській області, а також в Донецькій області. Водночас, в інших регіонах розмір середньої ЗП $\epsilon$ нижчим порівняно 3 середньою по Україні. Показово, що найнижчий рівень оплати праці має місце в Тернопільській, Чернівецькій та Чернігівській областях.

Дослідження рівня оплати праці у розрізі вікових груп населення (рис. 4) свідчить, що найвищий рівень ЗП має місце у 
віковій групі 35-44 та 25-34 роки. Водночас найнижчий рівень оплати праці має місце у віковій групі населення до 25 років, що вказує на високий рівень соціальної вразливості молоді на ринку праці.

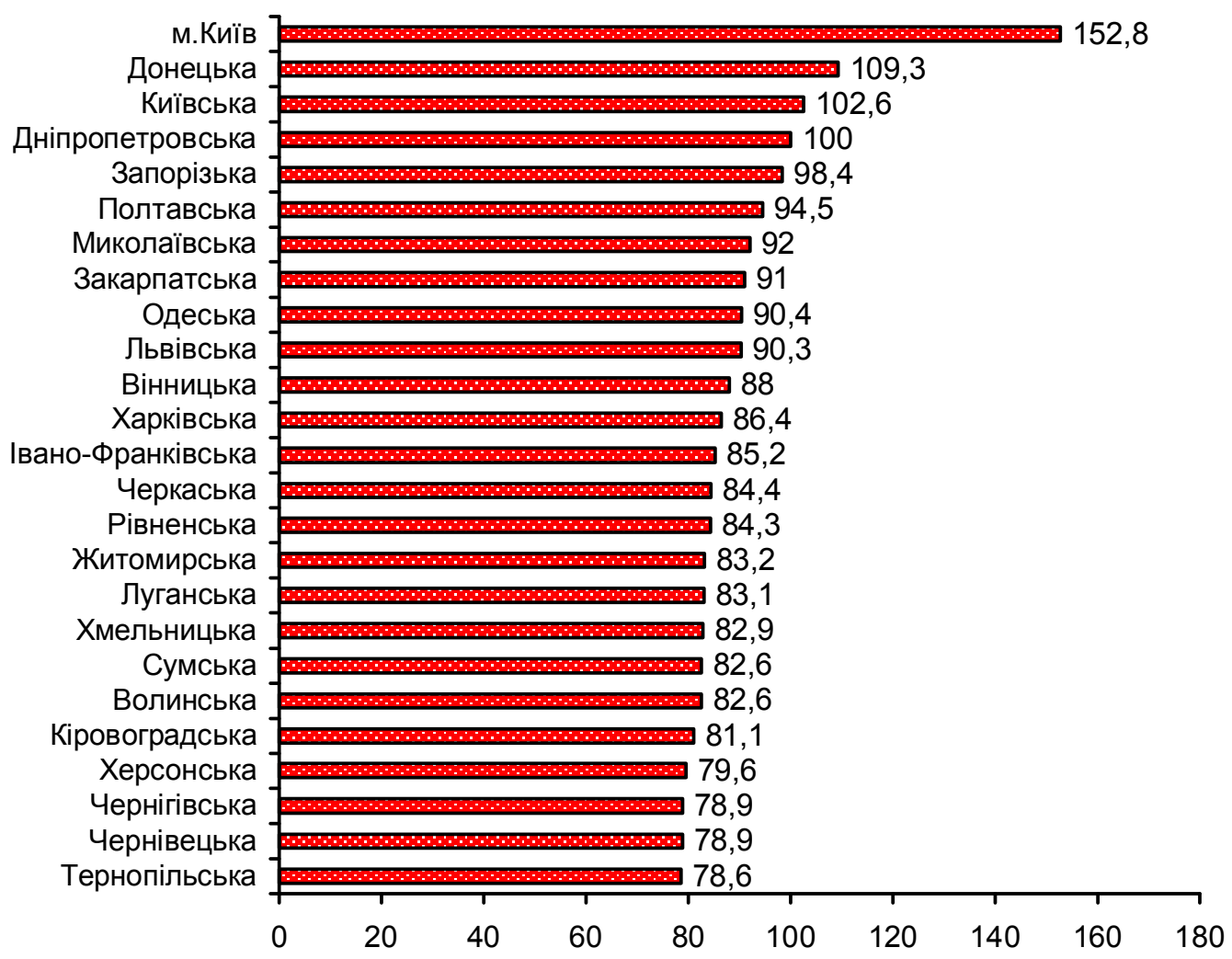

Рис. 3. Регіональна диференціація середньої заробітної плати в Україні, \% до середньої заробітної плати в національній економіці (2018р.) Джерело: побудовано автором на основі [4; 5]

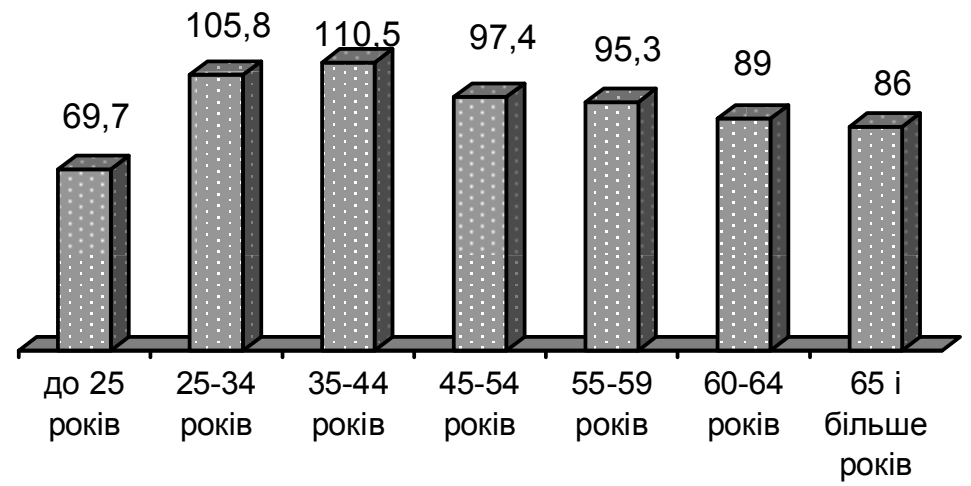

Рис. 4. Диференціація в оплаті праці за віковими групами (за результатами опитування працівників Держстатом України), \% до середньої заробітної плати Джерело: побудовано автором на основі [5]

Дослідження рівня оплати праці за формами власності суб'єктів господарювання (рис. 5) дає право стверджувати, що найнижчий 
рівень зарплати має місце серед приватних підприємств. Однак, наведені статистичні дані враховують лише так звану легальну ЗП. Відтак, є підстави стверджувати, що реальний рівень заробітної плати на приватних підприємства з урахуванням ії тіньової складової $\epsilon$ суттєво вищим. В той же час, з огляду на прозорість оплати праці в органах державної влади, офіційні статистичні дані вказують про суттєво вищий рівень оплати праці саме в них.

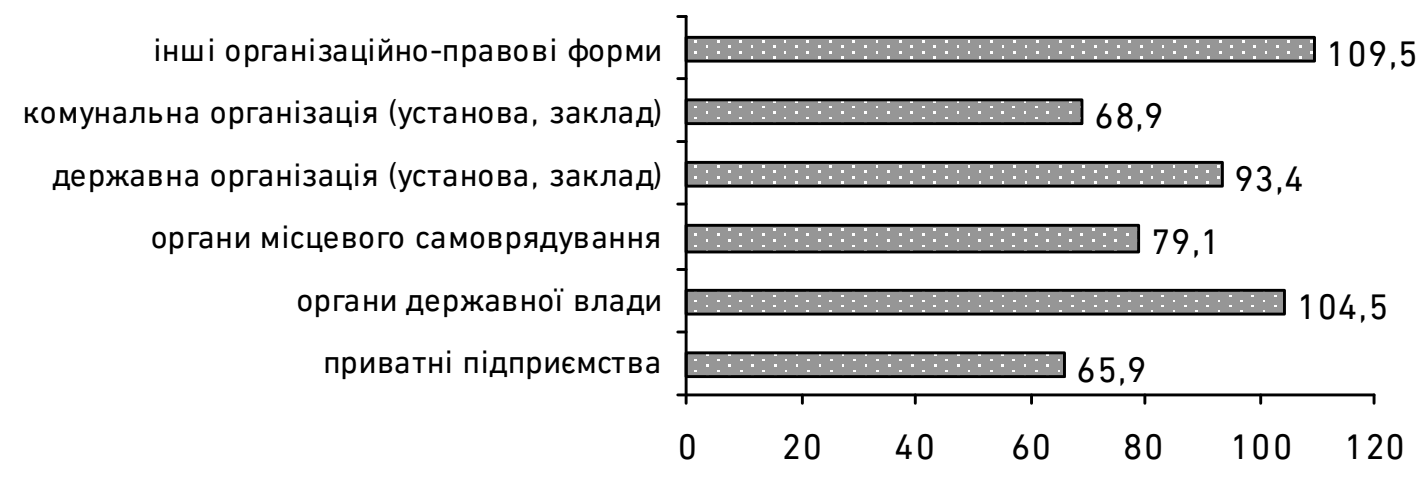

Рис. 5. Диференціація в оплаті праці за формами власності суб'єктів господарювання, \% до середньої заробітної плати (2018р.)

Джерело: побудовано автором на основі [5]

Аналіз даних щодо застосування існуючих форм оплати праці вказує, що в національній економіці більш поширеною є погодинна форма оплати праці, частка охоплення працівників якою складає понад 94\%. Водночас, за відрядною формою здійснюється оплата праці лише 5,8\% працівників.

Дослідження рівня оплати праці за ознакою статі (рис. 6) свідчить про наявність так званого «гендерного розриву». Так, найнижчий рівень оплати праці жінок порівняно з чоловіками спостерігається в сфері мистецтва, спорту та відпочинку, а також фінансовій та страховій діяльності. Не значний рівень гендерного розриву в заробітній платі має місце в освіті, у сфері адміністративного та допоміжного обслуговування, державному управлінні та обороні. Загалом, нижчий рівень ЗП жінок на національному ринку праці можна пояснити низкою як об'єктивних, так і суб'єктивних факторів. На наше переконання, до перших із них можна віднести переважання частки чоловіків на роботах з важкими та шкідливими умовами праці (передбачені відповідні доплати), на керівних посадах. Поміж суб'єктивних факторів гендерної нерівності в оплаті праці варто виділити світоглядні та ментальні стереотипи, виконання жінками репродуктивної та виховної функції тощо. Таким чином, можна констатувати, що на національному ринку праці жінки належать до соціально вразливих категорій населення за рівнем оплати праці. 


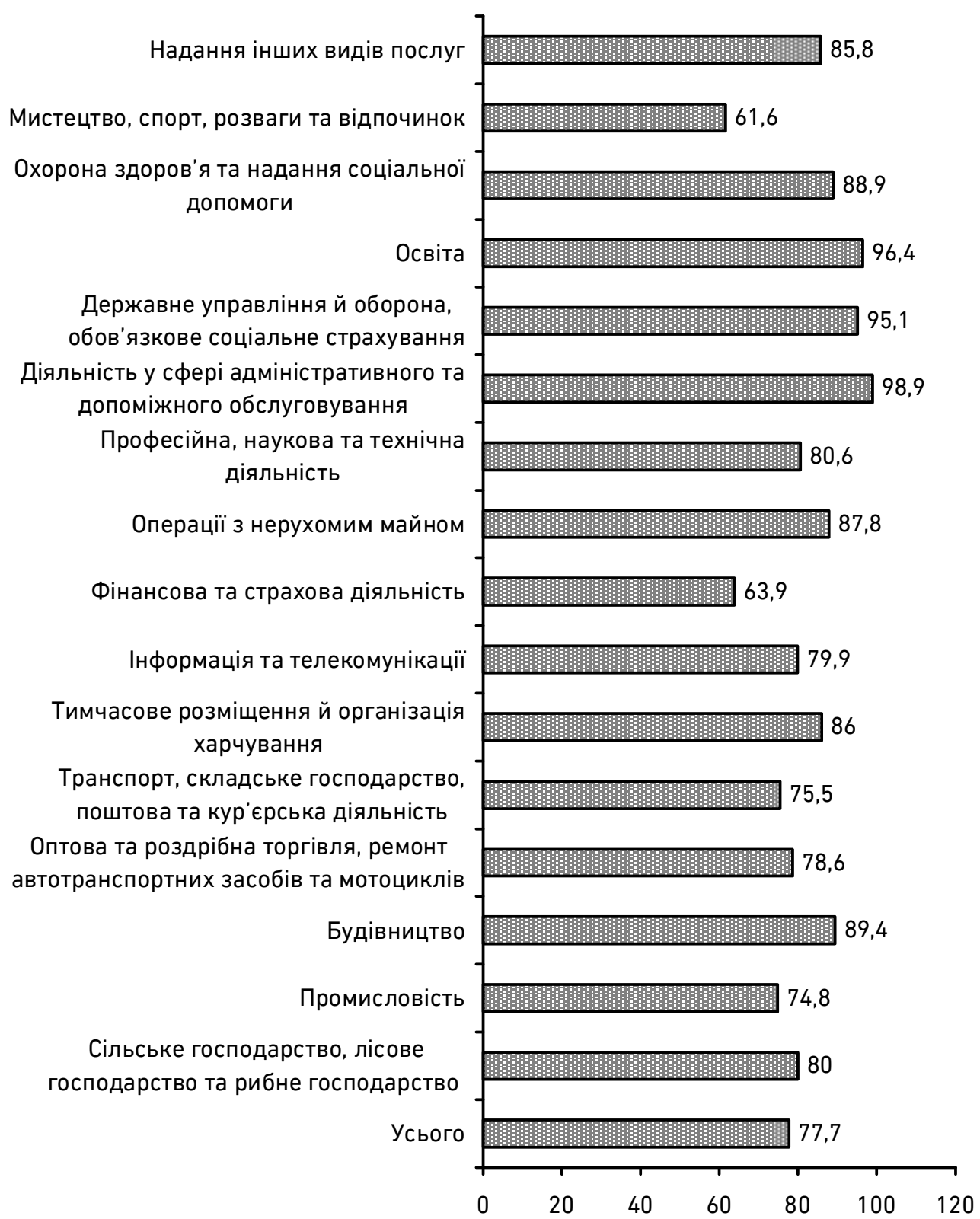

Рис. 6. Співвідношення заробітної плати жінок і чоловіків, \% Джерело: побудовано автором на основі [4; 5]

Аналіз фонду оплати праці в національній економіці (рис. 7) дає право стверджувати, що в його структурі близько $57 \%$ припадає на фонд основної заробітної плати, в той час як на заохочувальні та компенсаційні виплати - лише 6\%. Частка фонду додаткової заробітної плати у 2018 р. складала $37 \%$. При цьому в структурі останнього на преміальні виплати припадало близько $38 \%$, на доплати та надбавки - 35\% (рис. 8). 


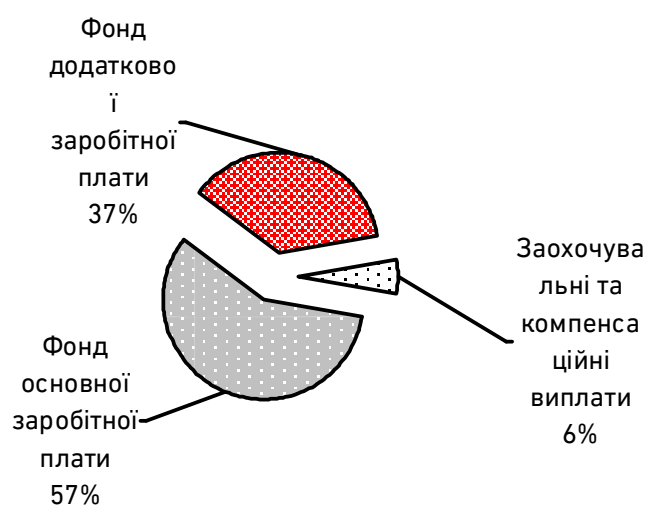

Рис. 7. Структура фонду оплати праці (2018), \%

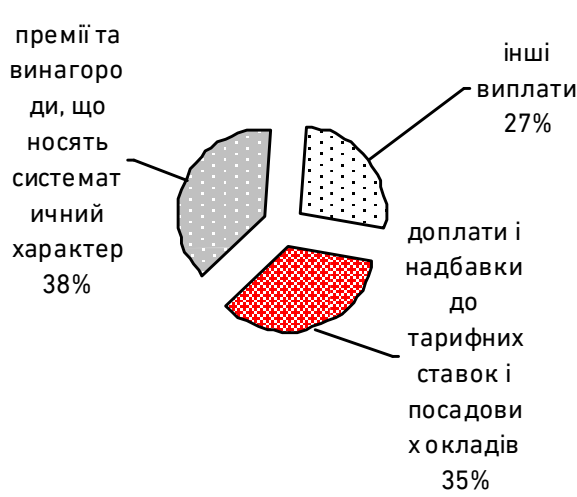

Рис. 8. Структура фонду додаткової заробітної праці (2018), \%

Джерело: побудовано автором на основі [4; 5; 7]

Аналіз рівня оплати праці в ЄС та Україні (рис. 9) свідчить що в $€ C$ годинна заробітна плата варіює в межах від 2,3 до 41 євро.

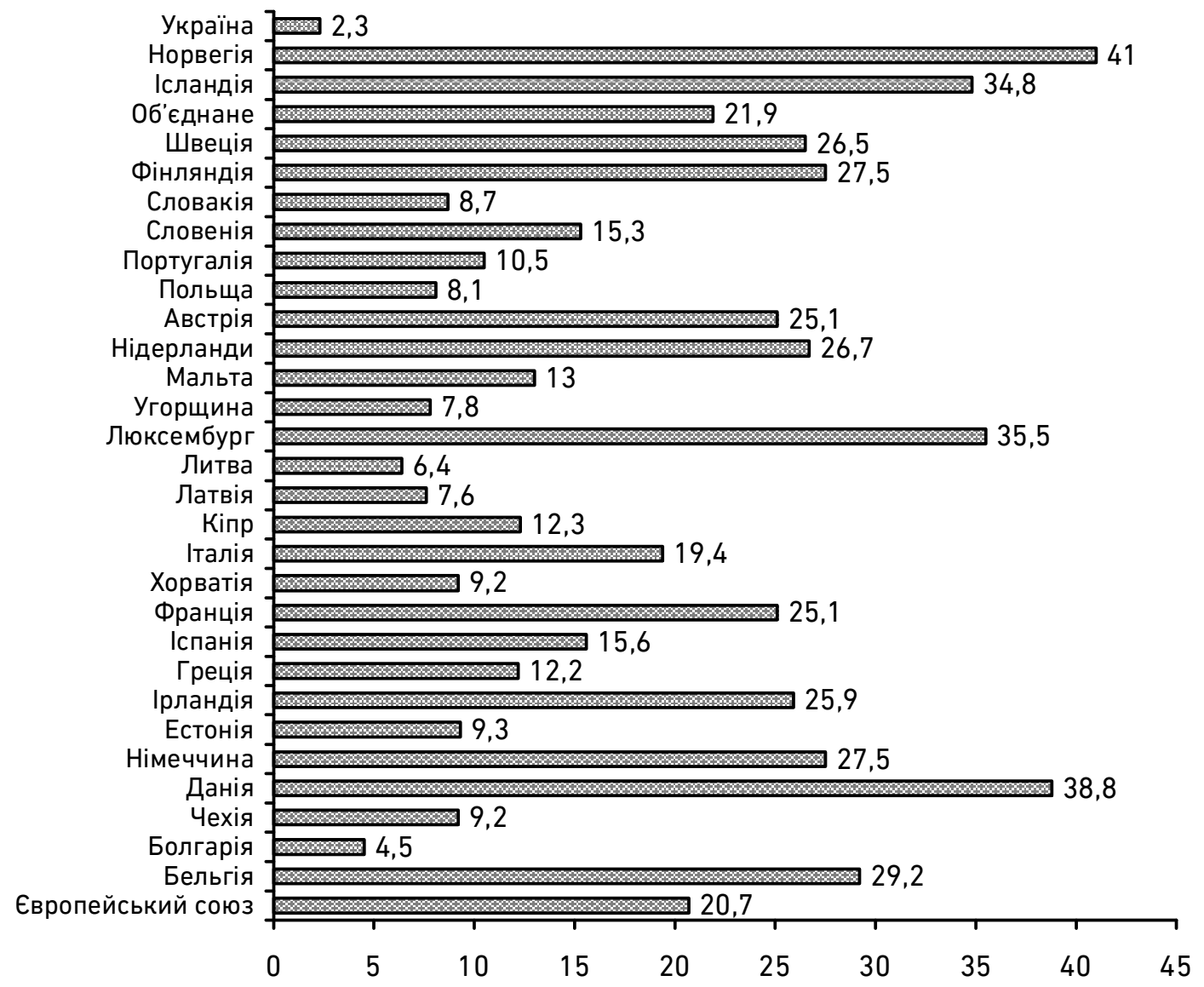

Рис. 9. Рівень годинної оплати праці в державах ЄС та Україні (2018р.), євро/годину

Джерело: побудовано автором на основі [4; 5; 7] 
Найменша оплата за годину роботи серед держав ЄС має місце в Болгарії, найвища - в Данії та Норвегії. Щодо України, то порівняно 3 європейським ринком праці в національній економіці спостерігається критично низький рівень оплати праці 2,3 євро/годину, що практично вдвічі $€$ нижчим за рівень заробітної плати в Болгарії та у вісімнадцять разів нижче порівняно 3 Норвегією.

Висновки і пропозиції. Аналіз оплати праці на національному ринку праці дозволив виявити такі особливості та проблеми:

- темпи зростання номінальної заробітної плати протягом 20142018 рр. варіювали в межах від 6,0 до 37,1\%;

- протягом 2014-2015 рр. в Україні мало місце суттєве зниження реальної заробітної плати відповідно на 6,5 та 20,2\%;

- має місце диференціація оплати праці за видами економічної діяльності (найвища зарплата спостерігається у фінансовій та страховій діяльності, найнижча - охороні здоров'я та наданні соціальної допомоги);

- найвищий рівень оплати праці спостерігається в Київській та Донецькій області, найнижчий - Тернопільській та Чернігівській області;

- найвищий рівень заробітної плати має місце у віковій групі 3544 та 25-34 роки, найнижчий - у віковій групі до 25 років;

- В національній економіці більш поширеною $€$ погодинна форма оплати праці, частка охоплення працівників якою складає понад 94\%;

- найнижчий рівень зарплати має місце серед приватних підприємств, найвищий - в органах державної влади;

- в Україні має місце значний гендерний розрив в оплаті праці (близько 23\% на користь чоловіків);

- в структурі заробітної плати близько 57\% припадає на фонд основної заробітної плати, в той час як на заохочувальні та компенсаційні виплати припадає лише 6\%;

- порівняно 3 європейським ринком праці в національній економіці спостерігається критично низький рівень оплати праці 2,3 євро/годину, що практично вдвічі $\epsilon$ нижчим за рівень заробітної плати в Болгарії та у вісімнадцять разів нижче порівняно 3 Норвегією.

Удосконалення оплати праці в Україні повинно базуватися на ряді принципів, поміж яких варто виділити принцип соціальної справедливості, диференціації оплати праці, соціальної безпеки, невпинного зростання реальної заробітної плати, відповідність 
заробітної плати вартості робочої сили та ін.

Серед основних напрямів удосконалення регулювання оплати праці в Україні варто виділити: запровадження моніторингу впливу заробітної плати на основні соціально-економічні показники розвитку; забезпечення формування заробітної плати у відповідності до ринкової вартості робочої сили; активне залучення до процесу удосконалення механізму формування заробітної плати всіх суб'єктів ринку праці; забезпечення широкого застосування в економіці України гнучких та багатофакторних форм оплати праці (макрорівень); забезпечення тісного зв'язку розміру заробітної плати від індивідуальних результатів трудової діяльності кожного працівника; забезпечення прямої залежності заробітної плати від ефективності діяльності підприємства (рівень підприємства).

1. Голосніченко Д. І., Довжик А. М. Оплата праці: проблеми та шляхи вирішення. ВІСНИК НТУУ «КПІ». Політологія. Соціологія. Право. 2014. Вип. $3 / 4$ (23/24). С. 185189. 2. Ільєнко Н., Спасенко Ю. Забезпечення оптимальної диференціації заробітної плати - важливий напрям регулювання оплати праці. Україна: аспекти праці. 2015. № 1, 2015. С. 22-27. 3. Колот А. М. Організаційно-економічний механізм регулювання заробітної плати i шляхи його вдосконалення (на матеріалах промислових підприємств України) : автореф. дис. ... д-ра екон. наук : 08.06.01. Київ. 1998. 36 с. 4. Оплата праці та соціально-трудові відносини: статистична інформація. Державна служба статистики України. URL: http://www.ukrstat.gov.ua (дата звернення: 20.01.2020). 5. Праця в Україні у 2018 році : статистичний збірник. Державна служба статистики України. URL: http://www.ukrstat.gov.ua 6. Про оплату праці : Закон України від 24.03.1995 № 108/95-ВР. Дата оновлення: 13.02.2020. URL: $\quad$ https://zakon.rada.gov.ua/laws/card/108/95-\%D0\%B2\%D1\%80 (дата звернення: 20.01.2020). 7. Earnings (Database 2015-2018) / European Commission. Eurostat. URL: http://ec.europa.eu/eurostat/data/database (дата звернення: 20.01.2020).

\section{REFERENCES:}

1. Holosnichenko D. I., Dovzhyk A. M. Oplata pratsi: problemy ta shliakhy vyrishennia. VISNYK NTUU «KPI». Politolohiia. Sotsiolohiia. Pravo. 2014. Vyp. 3/4 (23/24). S. 185-189. 2. Ilienko N., Spasenko Yu. Zabezpechennia optymalnoi dyferentsiatsii zarobitnoi platy - vazhlyvyi napriam rehuliuvannia oplaty pratsi. Ukraina: aspekty pratsi. 2015. № 1, 2015. S. 22-27. 3. Kolot A. M. Orhanizatsiino-ekonomichnyi mekhanizm rehuliuvannia zarobitnoi platy i shliakhy yoho vdoskonalennia (na materialakh promyslovykh pidpryiemstv Ukrainy) : avtoref. dys. ... d-ra ekon. nauk : 08.06.01. Kyiv. 1998. 36 s. 4. Oplata pratsi ta sotsialno-trudovi vidnosyny: statystychna informatsiia. Derzhavna sluzhba statystyky Ukrainy. URL: http://www.ukrstat.gov.ua (data zvernennia: 20.01.2020). 5. Pratsia v Ukraini u 2018 rotsi : statystychnyi zbirnyk. Derzhavna sluzhba statystyky Ukrainy. URL: http://www.ukrstat.gov.ua (дата звернення: 20.01.2020). 6. Pro oplatu pratsi : Zakon Ukrainy vid 24.03.1995 № 108/95-VR. Data onovlennia: 13.02.2020. URL: https://zakon.rada.gov.ua/laws/card/108/95-\%D0\%B2\%D1\%80 (data zvernennia: 20.01.2020). 7. Earnings (Database 2015-2018) / European 
Yurchyk H. M., Candidate of Economics (Ph.D.), Associate Professor, Duzhar A. I., Senior Student (National University of Water Management and Environmental Engineering, Rivne)

\section{WAGES ON THE NATIONAL LABOR MARKET: DYNAMIC, REGIONAL-SECTORAL AND SOCIAL ASPECT}

The article examines the main trends in the wage in the national labor market. The analysis of remuneration in the national labor market revealed the following features and problems: the growth rates of nominal wages during 2014-2018 varied from 6.0 to $37.1 \%$; during 2014-2015, there was a significant decrease in real wages by $6.5 \%$ and $20.2 \%$ respectively in Ukraine; there is a differentiation of wages by type of economic activity (the highest wages are observed in financial and insurance activities, the lowest - in health care and social assistance); the highest level of remuneration is observed in Kyiv and Donetsk region, the lowest - in Ternopil and Chernihiv region; the highest level of wages occurs in the age group 35-44 and 2534 years, the lowest - in the age group up to 25 years; in the national economy, the hourly wage is more widespread, with workers reaching more than 94\%; the lowest wage level occurs among private enterprises, the highest - in public authorities; there is a significant gender pay gap in Ukraine (about $23 \%$ in favor of men); in the structure of wages, about $57 \%$ falls on the basic wage fund, while the incentive and compensatory payments account for only $6 \%$; Compared to the European labor market in the national economy, there is a critically low level of remuneration 2.3 Euros / hour, which is almost twice below the level of wages in Bulgaria and eighteen times lower than in Norway. Priority directions of improvement of regulation of remuneration in the national labor market are offered. Improving wages in Ukraine should be based on a number of principles, among which should be highlighted the principle of social justice, differentiation of wages, social security, continuous growth of real wages, compliance with wages and labor costs. Among the main areas for improving the regulation of wages in Ukraine are the following: introduction of monitoring the impact of wages on the main socio-economic indicators of development; ensuring that wages are formed in accordance with the market value of labor; active involvement in the process of improving the mechanism of wage formation of all subjects of the labor market; ensuring the widespread use in the Ukrainian economy of flexible forms; ensuring a close relationship between the wages and salaries and salaries of each 
employee's individual performance; ensuring a direct dependence of wages on the efficiency of the enterprise.

Keywords: salary; wages; labor market; real wages; nominal wages.

\begin{abstract}
Юрчик Г. Н., К.э.н., доцент, Дужар А. И., соискатель высшего образования первого (бакалаврского) уровня (Национальный университет водного хозяйства и природопользования, г. Ровно)

\section{ЗАРАБОТНАЯ ПЛАТА НА НАЦИОНАЛЬНОМ РЫНКЕ ТРУДА: ДИНАМИЧЕСКИЙ, РЕГИОНАЛЬНО-ОТРАСЛЕВОЙ И СОЦИАЛЬНЫЙ АСПЕКТ}

Исследованы основные тенденции в оплате труда на национальном рынке труда. Проанализировано изменение номинальной и реальной заработной платы, отраслевую и региональную дифференциацию в оплате труда. Обоснованно социальную уязвимость молодежи и женщин на рынке труда по уровню их заработной платы. Выявлены особенности оплаты труда по организационным формам ведения бизнеса и по сравнению с европейским рынком труда. Предложены приоритетные направления совершенствования регулирования оплаты труда на национальном рынке труда.

Ключевые слова: заработная плата; оплата труда; рынок труда; реальная заработная плата; номинальная заработная плата.
\end{abstract}

